\title{
Sensitometric Comparisons of Insight and Ektaspeed Plus Films: Effects of Chemical Developer Depletion
}

\author{
Marcia Spinelli CASANOVA \\ Francisco HAITER-NETO \\ Frab Norberto BÓSCOLO \\ Solange Maria de ALMEIDA
}

Department of Oral Diagnosis, Faculty of Dentistry of Piracicaba, State University of Campinas, Piracicaba, SP, Brazil

\begin{abstract}
The aim of this study was to compare the sensitometric properties of Insight and Ektaspeed Plus radiographic films manually and automatically processed using fresh and depleted chemical solutions. Ten sets of each type of film were obtained ( 1 set $=5$ films), 5 sets being manually processed and 5 sets being automatically processed. A total of 100 films (50 Ektaspeed Plus and 50 Insight film) were exposed and developed. The first two sets of each film type were developed in fresh chemicals (one set per each type of processing), on the first day of the experiment. The other sets were processed in the same progressively depleted solutions once a week until the end of experiment, which was completed within 4 weeks. Characteristic curves were constructed to compare the sensitometric properties of the films: contrast, latitude and speed. Processing solution depletion had different effects on manually and automatically developed films, which was confirmed by the changes in the form of the characteristic curves in the third week of the automatic processing and fourth week of the manual processing. Ektaspeed Plus showed 11\% reduction in contrast values for manual processing and 53\% for automatic processing, while Insight contrast values showed a reduction of $25 \%$ and $59 \%$, respectively. Insight film, however, showed lesser loss of speed and lesser increase of latitude than Ektaspeed Plus. In conclusion, chemical depletion in automatic film processing was faster than in manual developing. In depleted chemicals, both types of films had an increase in latitude values and a decrease in speed and contrast. Insight was more resistant than Ektaspeed Plus to decrease in speed and latitude when processed using older chemicals, whereas contrast in Ektaspeed Plus was comparatively more stable.
\end{abstract}

Key Words: X-ray film, dental radiography, chemical depletion.

\section{INTRODUCTION}

A major objective of diagnostic radiology is to provide images of optimal quality at radiation doses as low as reasonably achievable (1). The development of dental radiology has been characterized by a progressive increase in X-ray film speed and a consequent reduction in radiation hazards (2).

Ektaspeed film (Eastman Kodak Co., Rochester, NY, USA) was introduced to the market in early 1981, but presented several disadvantages. To overcome these shortcomings, Ektaspeed Plus film (Eastman Kodak Co.) was launched in 1994. Based on tabular grain technology, Ektaspeed Plus film yielded a 50\% radiation dose reduction in comparison to D- or Ultra- speed films, while providing comparable image quality. In April 2000, Insight film (Eastman Kodak Co.) was introduced to the market, classified as an F-speed intraoral film when processed in a roller-transport automatic processor. Insight was $20 \%$ faster than Ektaspeed Plus, while maintaining the same image quality.

Image quality is also influenced by the processing method and it has been observed that depletion of processing chemicals can have a deleterious effect on film sensitometric properties (3). Therefore, the goal of this study was to compare the sensitometric properties of Insight and Ektaspeed Plus radiographic films manually and automatically processed using fresh and depleted chemical solutions. 


\section{MATERIAL AND METHODS}

Ektaspeed Plus and Insight radiographic films (Eastman Kodak Co.) were used. Ektaspeed Plus is an E-speed film, while Insight is classified as an F-speed film when processed in roller-type automatic processors. Film exposures were made with a GE 1000 dental X-ray equipment (General Electric Co.; Milwaukee, WI, USA) operating at $70 \mathrm{kVp}$ and $10 \mathrm{~mA}$, with 2.5 -mm aluminum filtration. A 20-cm source-film distance was set for all exposures by placing the $\mathrm{X}$-ray tube head in a jig that provided fixed orientation of the central beam and film.

Insight and Ektaspeed Plus films were coded by exposure time using a system of lead letters placed at film periphery. The films were exposed in the same position and exposures were made in 4 increments: 1 , 10, 60 and 300 impulses. Four exposed films plus an additional unexposed film (used to determine base-plusfog density) formed one set of dental films. Ten sets of each type of film were obtained, five sets being manually processed and five sets being automatically processed. A total of 100 films (50 Ektaspeed Plus and 50 Insight) were exposed and developed.

All films were developed using GBX chemicals (Kodak Brasileira Indústria e Comércio Ltda, São José dos Campos, SP, Brasil) for manual processing and Kodak RP-XOMAT (Kodak Brasileira Indústria e Comércio Ltda) for automatic processing. Automatic processing temperature was set at $28^{\circ} \mathrm{C}$ in an automatic film developer (GXP; Gendex Dental Systems, Des Plaines, IL, USA) with a 6-min cycle. Manual developing time was 4 min at $20^{\circ} \mathrm{C}$.

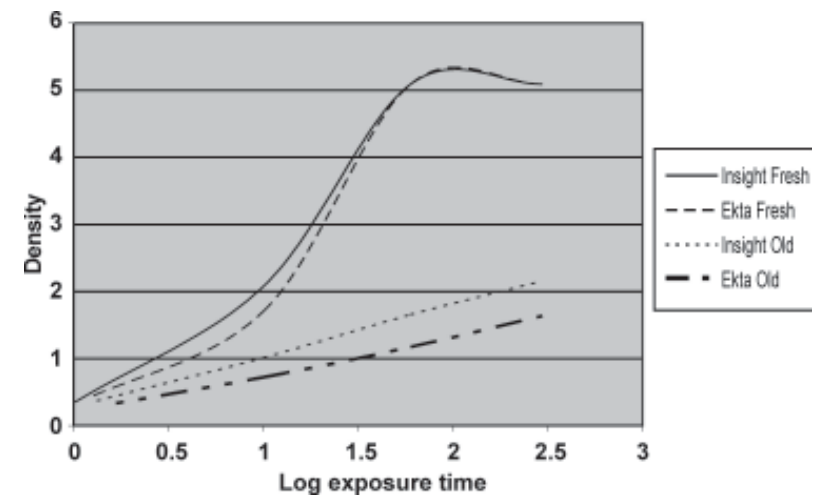

Figure 1. Characteristic curves of Insight and Ektaspeed Plus films using manual processing with fresh and old chemicals.
The first two sets of each film type were processed in fresh chemicals (one set was manually developed and the other was automatically developed), on the first day of the experiment. The other sets were processed in progressively depleted solutions once a week until the end of experiment. The 1st, 5th, 12th, 19th and 26th days were settled as processing days and the study was completed within 4 weeks. After processing, film densities were measured with a digital densitometer (MRA Company, Ribeirão Preto, SP, Brazil) with a 2$\mathrm{mm}$ aperture. Optical density was measured at five points across the surface of each degree of density. An average density was determined for each film.

Characteristic curves for each film type, processing system and processing day were constructed by plotting the optical density against the logarithm of exposure in compliance with ISO standard 5799 (4).

The characteristic curves were used to calculate film speed, inherent contrast and exposure latitude. Film speed was calculated as the exposure time (in seconds) required to produce a density of 1.0 above base-plusfog (5). Calculation of speed used nonlogarithmic numbers for exposure time. Contrast was determined in the 0.25-2.0 net density range (6). Latitude was calculated as the difference between exposure times needed to produce 1.0 and 2.0 above base-plus-fog (5).

\section{RESULTS}

The characteristic curves of Ektaspeed Plus and Insight films developed in the first and last days of the experiment are shown in Figures 1 and 2.

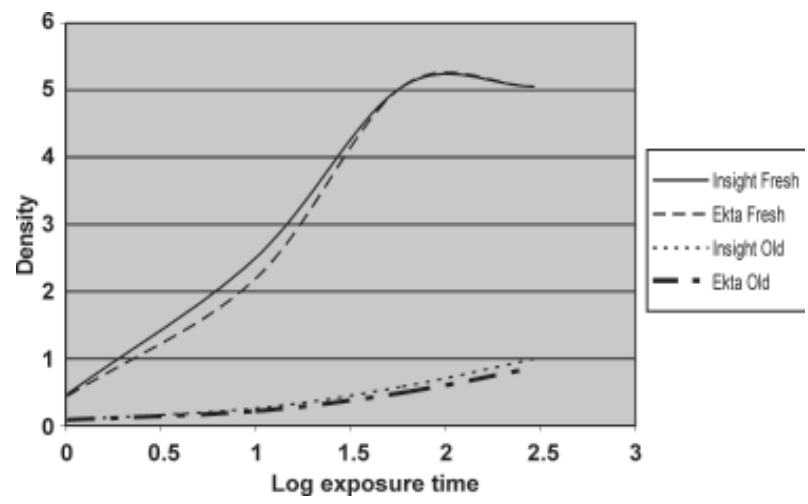

Figure 2. Characteristic curves of Insight and Ektaspeed Plus films using automatic processing with fresh and old chemicals. 
The shift of curves along the $\mathrm{X}$ axis indicates the difference in the speed of the two films. Insight film (curve on the left) was faster than Ektaspeed Plus (curve on the right) under both processing conditions because lesser exposure is required to produce the same level of density (7). This difference was observed in both fresh and old chemicals.

The effects of depletion of chemical solutions on the characteristic curves are shown in Figures 3 to 6. Depletion changed the form of the characteristic curves, which became more linear and occurred faster under automatic rather than manual processing.

The degradation of chemicals used in automatic developing is visually detectable in the characteristic curves recorded at the end of the third and fourth weeks

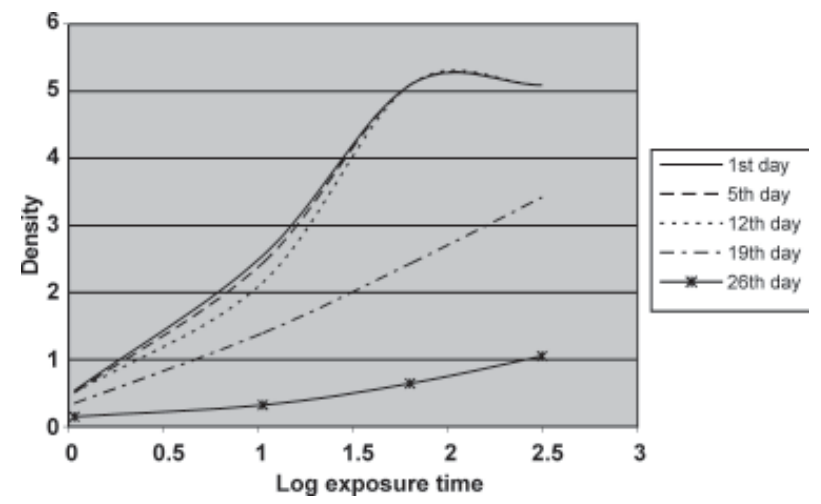

Figure 3. Effects of solution depletion on characteristic curves of automatically processed Insight film.

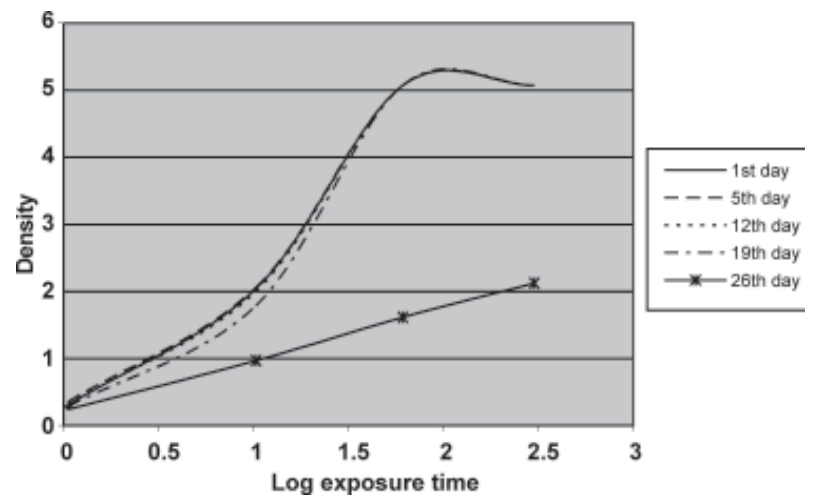

Figure 5. Effects of solution depletion on characteristic curves of manually processed Insight film.
(Figs. 3 and 4). Under manual conditions, this effect is only noted at the end of the fourth week (Figs. 5 and 6). As the solutions became degraded, the curves of both films shifted to the right in relation to the previous processing day, which indicates that there was a decrease in film speed.

The base-plus-fog densities for all combinations of film types, processing techniques and processing days are shown in Table 1. Base-plus-fog densities were similar for both films, regardless of the processing technique. Although base-plus-fog densities were higher for automatic processing in the first two weeks, at the end of third week the values were similar in both processing conditions. Base-plus-fog levels complied with ISO standard 3665 specifications (8).

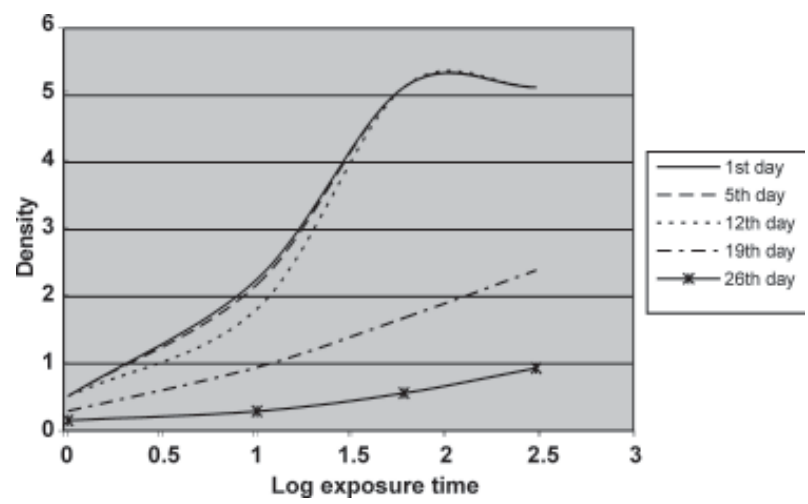

Figure 4. Effects of solution depletion on characteristic curves of automatically processed Ektaspeed Plus film.

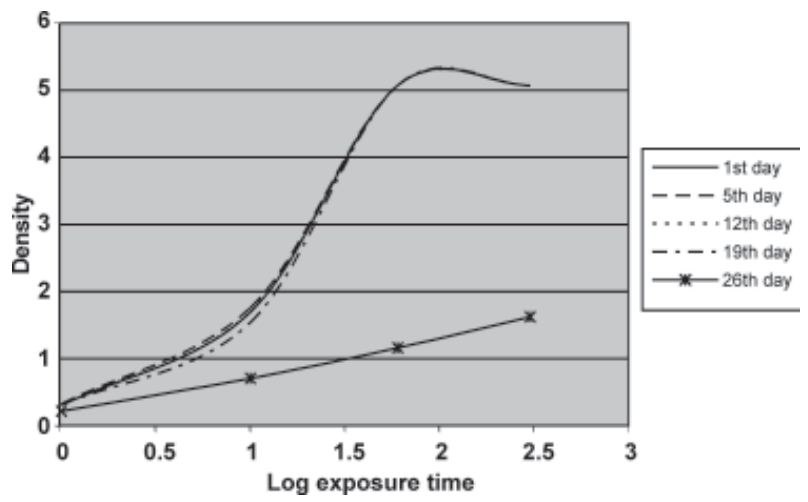

Figure 6. Effects of solution depletion on characteristic curves of manually processed Ektaspeed Plus film. 
The contrast values are shown in Table 2. In the 0.25 to 2 density ranges, the average gradient for Insight film was higher than Ektaspeed Plus on the first day of processing. From the beginning of the experiment to the end of the first week, contrast in both films was higher when automatically processed. However, from the end of the second week to the end of the experiment this situation reversed. Regardless of the processing condition, the contrast values of both films decreased secondary to solution depletion. At the end of the experiment, manually processed Ektaspeed Plus and Insight films showed $11 \%$ and $25 \%$ reduction in contrast values, respectively, whereas automatically processed Ektaspeed Plus and Insight films showed 53\% and 59\% contrast reduction, respectively. Interestingly, under

Table 1. Base-plus-fog density of both films manually and automatically processed on different days.

\begin{tabular}{lccccc}
\hline Day & \multicolumn{2}{c}{ Manual processing } & & \multicolumn{2}{c}{ Automatic processing } \\
\cline { 2 - 2 } & $\begin{array}{c}\text { Ektaspeed } \\
\text { Plus }\end{array}$ & Insight & & $\begin{array}{c}\text { Ektaspeed } \\
\text { Plus }\end{array}$ & Insight \\
& & & & \\
\hline 1st & 0.14 & 0.15 & & 0.31 & 0.34 \\
5th & 0.14 & 0.15 & & 0.31 & 0.28 \\
12th & 0.15 & 0.15 & & 0.29 & 0.28 \\
19th & 0.15 & 0.15 & & 0.13 & 0.14 \\
26th & 0.13 & 0.14 & & 0.11 & 0.12 \\
\hline
\end{tabular}

$\mathrm{a}=$ end of first week; $\mathrm{b}=$ end of second week; $\mathrm{c}=$ end of third week; $d$ = end of fourth week and of the experiment.

Table 3. Latitude values for Ektaspeed Plus and Insight films manually and automatically processed on different days.

\begin{tabular}{|c|c|c|c|c|}
\hline \multirow[t]{2}{*}{ Day } & \multicolumn{2}{|c|}{ Manual processing } & \multicolumn{2}{|c|}{ Automatic processing } \\
\hline & $\begin{array}{l}\text { Ektaspeed } \\
\text { Plus }\end{array}$ & Insight & $\begin{array}{l}\text { Ektaspeed } \\
\text { Plus }\end{array}$ & Insight \\
\hline $1 \mathrm{st}$ & 0.42 & 0.50 & 0.51 & 0.50 \\
\hline $5 t^{\mathrm{a}}$ & 0.43 & 0.50 & 0.50 & 0.50 \\
\hline 12 th $^{\mathrm{b}}$ & 0.32 & 0.59 & 0.38 & 0.50 \\
\hline 19 th $^{\mathrm{c}}$ & 0.46 & 0.45 & 1.01 & 0.82 \\
\hline 26 th $^{\mathrm{d}}$ & 1.40 & 1.31 & 0.84 & 0.81 \\
\hline
\end{tabular}

$\mathrm{a}=$ end of first week; $\mathrm{b}=$ end of second week; $\mathrm{c}=$ end of third week; $d$ = end of fourth week and of the experiment. manual developing conditions, contrast, was sometimes slightly greater for both types of films processed in old solutions.

The latitude values for Insight and Ektaspeed Plus films are given in Table 3. As the solutions became depleted, an increase in latitude was observed for both films. In manual development, there was an increase of 233\% in latitude for Ektaspeed Plus and of 162\% for Insight film at the end of the fourth week. In automatic processing, Insight film showed an increase of $64 \%$ in latitude and Ektaspeed Plus increased $98 \%$ at the end of third week, whereas at the end of experiment the increase in latitude was similar for both types of films.

Table 4 shows the exposure time in seconds necessary for a density of 1 , for both films developed

Table 2. Contrast values for Ektaspeed Plus and Insight films manually and automatically processed on different days.

\begin{tabular}{lccccc}
\hline Day & \multicolumn{2}{c}{ Manual processing } & & \multicolumn{2}{c}{ Automatic processing } \\
\cline { 2 - 3 } \cline { 5 - 6 } & $\begin{array}{c}\text { Ektaspeed } \\
\text { Plus }\end{array}$ & Insight & & $\begin{array}{c}\text { Ektaspeed } \\
\text { Plus }\end{array}$ & Insight \\
& 1.62 & 1.75 & & 1.80 & 1.98 \\
\hline 1st & 1.50 & 1.75 & & 1.70 & 1.96 \\
5 th $^{\mathrm{a}}$ & 1.75 & 1.54 & & 1.62 & 1.75 \\
$12 \mathrm{th}^{\mathrm{b}}$ & 1.62 & 1.66 & & 0.83 & 1.13 \\
$19 \mathrm{th}^{\mathrm{c}}$ & 1.40 & 1.31 & & 0.84 & 0.81 \\
\hline 26th & & & & & \\
\hline
\end{tabular}

$\mathrm{a}=$ end of first week; $\mathrm{b}=$ end of second week; $\mathrm{c}=$ end of third week; $d$ = end of fourth week and of the experiment.

Table 4. Speed for Ektaspeed Plus and Insight films manually and automatically processed on different days.

\begin{tabular}{lccccc}
\hline \multirow{2}{*}{ Day } & \multicolumn{2}{c}{ Manual processing } & & \multicolumn{2}{c}{ Automatic processing } \\
\cline { 2 - 3 } & $\begin{array}{c}\text { Ektaspeed } \\
\text { Plus }\end{array}$ & Insight & & $\begin{array}{c}\text { Ektaspeed } \\
\text { Plus }\end{array}$ & Insight \\
& & & & \\
\hline 1st & 0.085 & 0.056 & & 0.054 & 0.043 \\
5th & 0.079 & 0.052 & & 0.060 & 0.044 \\
12th & 0.087 & 0.059 & & 0.091 & 0.055 \\
19th & 0.085 & 0.074 & & 0.283 & 0.095 \\
26th & 0.874 & 0.252 & & 55.18 & 34.02 \\
\hline
\end{tabular}

$\mathrm{a}=$ end of first week; $\mathrm{b}=$ end of second week; $\mathrm{c}=$ end of third week; $d$ = end of fourth week and of the experiment. 
under manual and automatic conditions. Insight film was faster than Ektaspeed Plus in both types of processing. As the processing solutions were increasingly depleted, both films lost speed. Insight film lost less speed in both processing conditions.

\section{DISCUSSION}

The results of this study showed that different film types and processing conditions respond differently to depletion of chemicals, which is agreement with the findings of previous investigations (6,9-12).

The depletion process caused a change in the form of the characteristic curves. In manual processing, this change was observed only at the end of the last week, while in automatic development it occurred at the end of the third week. These outcomes could be attributed to the fact that developing solution depletion occurs faster in automatic processors than in manual tanks due to the higher temperature of the chemicals in the former.

When the chemicals were fresh, the highest contrast values were found in automatic processing, whereas manual processing provided higher contrasts when the solutions became depleted. This outcomes are consistent with those of previous studies $(6,13)$. In this study, Insight film yielded higher contrast values than Ektaspeed Plus in most cases, as reported by Ludlow et al. (11). However, other investigations $(3,6)$ have found similar contrast values for both types of films when developed using fresh solutions.

Contrast values decreased secondary to solution depletion (Table 2). This finding is consistent with those reported elsewhere $(1,5,14,15)$. Interestingly, depleted processing chemicals, in some cases, produced greater contrast for both films than fresh solutions, although the differences were small. Similar results have been reported (3). The smaller reduction in contrast values for Ektaspeed Plus, under both processing conditions, suggests that, regarding contrast, this film may be more resistant than Insight to the effects of depletion. The findings of the present study disagree with those of previous investigations $(6,11)$, which found that Ektaspeed Plus was more affected by processing conditions than Insight film.

Film latitudes were higher in depleted solutions than in fresh chemicals (Table 3), as reported by other authors $(5,14,16)$. In terms of latitude, Insight was more stable than Ektaspeed Plus.

The outcomes of this study clearly showed that Insight film is faster than Ektaspeed Plus, which is consistent with those of previous studies $(3,6,11,12,17,18)$. As the processing solution became depleted, both films lost speed (Table 4). Similar effects of depleted solutions on film speed have been reported $(3,5,14,16)$. Insight film lost lesser speed in this study. The smaller reduction in speed for Insight film suggests that this film may be more resistant than Ektaspeed Plus to the effects of solution depletion, as previously reported by Geist and Brand (3). On the other hand, Syriopoulos et al. (6) found that the speed of Ektaspeed Plus was less affected than the speed of Insight by processing conditions.

In conclusion, chemical depletion in automatic film processing was faster than in manual developing. In depleted chemicals, both types of films had an increase in latitude values and a decrease in speed and contrast. Insight film was more resistant than Ektaspeed Plus to decrease in speed and latitude when processed using older chemicals, whereas contrast in Ektaspeed Plus was comparatively more stable. Based on these findings, the use of Insight dental film could be suggested to reduce patient exposure to radiation.

\section{RESUMO}

O objetivo do presente estudo foi comparar as propriedades sensitométricas dos filmes Insight e Ektaspeed Plus processados manual e automaticamente em soluções novas e degradadas. Foram expostas 10 séries de cada tipo de filme ( 1 série $=5$ filmes), sendo 5 séries processadas manualmente e 5, automaticamente. As primeiras duas séries de cada filme foram processadas em líquidos novos (uma série para cada tipo de processamento) e as demais foram processadas nas mesmas soluções progressivamente degradadas, uma vez por semana, até a conclusão do experimento dentro de 4 semanas. Curvas características foram construídas a fim de se comparar as propriedades sensitométricas dos filmes: contraste, latitude e sensibilidade. A degradação das soluções apresentou comportamentos distintos entre os tipos de processamento, o que pôde ser visto pelo padrão das curvas características que apresentaram modificações em sua forma, na terceira semana no processamento automático e na quarta semana no processamento manual. O filme Ektaspeed Plus apresentou uma redução de 11\% nos seus valores de contraste no processamento manual e 53\% no automático, já o Insight, 25\% e 59\%, respectivamente. O filme Insight, no entanto, apresentou uma menor perda de sensibilidade e um menor aumento de latitude. Concluiu-se que a degradação é mais rápida no processamento automático do que no manual. Em soluções degradadas, ambos os filmes apresentaram aumento de latitude e redução de contraste e sensibilidade. O Insight foi mais 
resistente em relação à latitude e sensibilidade, mas quanto ao contraste, o Ektaspeed Plus se apresentou mais estável.

\section{REFERENCES}

1. Syriopoulos K, Velders XL, Sanderink GCH, van Ginkel FV, van der Selt PF. Sensitometric evaluation of four dental x-ray films using five processing solutions. Dentomaxillofac Radiol 1999;28:73-79.

2. Tamburus JR, Lavrador MAS. Radiographic contrast. A comparative study of three dental X-ray films. Dentomaxillofac Radiol 2001;26:201-205.

3. Geist JR, Brand JW. Sensitometric comparison of speed group $\mathrm{E}$ and $\mathrm{F}$ dental radiographic films. Dentomaxillofac Radiol 2001;30:147-152.

4. International Organization for Standardization. ISO 5799. Photography. Direct-exposing medical and dental radiographic film/process systems. Determination of ISO speed and ISO average gradient. 2nd ed. Geneva: ISO; 1991.

5. Thunthy KH, Weinberg R. Effects of developer exhaustion on Kodak Ektaspeed Plus, Ektaspeed and Ultra-speed dental films. Oral Surg Oral Med Oral Pathol 1995;79:117-121.

6. Syriopoulos K, Velders XL, Sanderink GCH, van der Selt PF. Sensitometric and clinical evaluation of a new F-speed dental X-ray film. Dentomaxillofac Radiol 2001;30:40-44.

7. White SC, Pharoah MJ. Oral radiology, principles and interpretation. 4th ed. Mosby: St Louis; 2000.

8. International Organization for Standardization. ISO 3665. Photography. Intra-oral dental radiographic film. Specification. 2nd ed. Geneva: ISO; 1996.

9. Ludlow JB, Platin E. Densitometric comparisons of Ultraspeed, Ektaspeed, Ektaspeed Plus intraoral films for two processing conditions. Oral Surg Oral Med Oral Pathol Oral
Radiol Endod 1995;79:105-113.

10. Syriopoulos K, Velders XL, Sanderink GCH, van Ginkel FV, van der Selt PF. Effects of developer exhaustion on the sensitometric properties of four dental films. Dentomaxillofac Radiol 1999;28:80-88.

11. Ludlow JB, Platin E, Mol A. Characteristics of Kodak Insight, an F-speed intraoral film. Oral Surg Oral Med Oral Pathol Oral Radiol Endod 2001;91:120-129.

12. Casanova MLS, Haiter-Neto F. Effects of developer depletion on image quality of Kodak Insight and Ektaspeed Plus films. Dentomaxillofac Radiol 2004;33:108-113.

13. Fletcher JC. A comparison of Ektaspeed and Ultraspeed films using manual and automatic processing solutions. Oral Surg Oral Med Oral Pathol 1987;63:94-102.

14. Sposto MR, Tavano O, Lopes ES. Sensitometric study of two developers (Kodak and Silib) for radiographic periapical dental films. Estomatol Cult 1983;13:61-67.

15. Ribeiro RF, Tavano O. Evaluation of the exhaustion of the Ray developing solution in the portable processing box. Braz Oral Res (formely Rev Odontol Univ São Paulo) 1993; 7:167-171.

16. Ribeiro A, Tavano O, Iucif Pereira PP. Comparative study of Hexa solution and its degradation by sensitometric method. J Appl Oral Sci (formely Rev Fac Odontol Bauru) 1994;2:6873.

17. Price C. Sensitometric evaluation of a new F-speed dental radiographic film. Dentomaxillofac Radiol 2001;30:29-34.

18. Sheaffer JC, Eleazer PD, Scheetz JP, Clark J, Farman AG. A comparison of D-, E- and F-speed conventional intraoral radiographic films in endodontic measurement. Oral Surg Oral Med Oral Pathol Oral Radiol Endod 2002;93:337-340.

Accepted March 27, 2006 